\title{
Sustainable Employment Generation for Livelihood through MGNREGA Programme in Chikaballapur District of Karnataka
}

\author{
Srikanth .K .N ${ }^{1}$ Rajmohan Rao ${ }^{2}$ \\ ${ }^{1} \mathrm{Ph} . \mathrm{D}$. Scholar, Center for study of Social Exclusion and Inclusive policy, Bharathidasan University, Palkalaiperur Tiruchirappalli,-24 \\ Tamil Nadu. \\ ${ }^{2}$ Professor \& Director, Centre for Study of Social Exclusion and Inclusive Policy, Bharathidasan University, Palkalaiperur Tiruchirappalli-
} 24 Tamil Nadu

\begin{abstract}
The MGNREGA aims at enhancing the livelihood security of the people in rural areas by guaranteeing hundred days of wage employment in a financial year to a rural household whose members volunteer to do unskilled manual work. The objective of the Act also includes creation of durable assets and strengthening the livelihood natural resource base of the rural poor. Providing employment to the rural poor enhances their livelihood security by increasing their earnings as well as the expenditure and thereby improves their standard of living. It also inculcates the habit of thrift in them. This helps the BPL families to cross the poverty line. Keeping the ambitious motive of the world's largest poverty alleviation programme in mind, a modest attempt is made in this study to assess the impact of MGNREGS on livelihood security of its participants and to what extent the scheme has been successful in achieving its objectives, in Chickaballapur district of Karnataka.
\end{abstract}

Keywords: MGNREGA, BPL, Employment generation NREGA and SC/ST

\section{Introduction}

The MGNREGA aims at enhancing the livelihood security of the people in rural areas by guaranteeing hundred days of wage employment in a financial year to a rural household whose members volunteer to do unskilled manual work. The objective of the Act also includes creation of durable assets and strengthening the livelihood natural resource base of the rural poor. The choice of work suggested in the Act addresses the causes of chronic poverty like drought, deforestation, soil erosion and so on, so that the process of employment generation is sustainable

\section{Scope of the Study}

National Rural Employment Guarantee Act (NREGA) was notified on September 7, 2005 and came into force on February 2, 2006. It is the world's biggest employment guarantee programme implemented in India. It aims at enhancing livelihood security of households in rural areas of the country by providing at least 100 days of guaranteed wage employment in a financial year to every household whose adult members volunteer to do unskilled manual work. Its primary objective is augmenting wage employment and strengthening natural resource management.

Job cards are issued for all the workers seeking employment for the maintenance of identity. Unemployment allowance is paid, if work is not assigned within 15 days of seeking employment. Wages are paid to the workers through their savings account opened in banks or post offices. Use of machineries which replace human labour are minimized. Wage rate for both men and women is the same. One third of the beneficiaries of NREGA should be women. It also provides equal opportunities for SCs, STs and other weaker sections of the society. An economic analysis of this programme is made in the study to assess as to what extent the programme has been successful in achieving

The specific objectives of the present study are:

1) Socio-economic features of the respondent households.

2) To estimate the complementary benefits of MGNREGS on income, expenditure and savings pattern of MGNREGS participants

\section{Hypotheses}

1) Income and savings of the MGNREGS participants is more than that of non-participants.

2) Consumption expenditure of MGNREGS participants is more than that of non-participants indicating improved nutritional security due to MGNREGS.

3) To assess the economic empowerment of women through MGNREGS.

\section{Hypotheses}

MGNREGS has facilitated greater involvement of women in different organizations, community activities and their household financial decision making.

\section{Methodology}

The research methodology in terms of conceptual and empirical framework followed and its operationalisation is discussed in this chapter. Chikkaballapura district was covered during the third phase of implementation of MGNREGS which was selected for the study with the pre set objective of analysing the socio-economic impact of MGNREGS on the participant households.

Both primary and secondary data were collected for analysis for the year 2014-15. Primary data from the MGNREGA participants related to their age, gender, employment,

\section{Volume 6 Issue 1, January 2017




\section{International Journal of Science and Research (IJSR) \\ ISSN (Online): 2319-7064 \\ Index Copernicus Value (2015): 78.96 | Impact Factor (2015): 6.391}

income, savings, consumption expenditure and other socioeconomic parameters and from the farmers about the labour availability for agriculture is collected through structured and pre-tested schedules. Similarly secondary data on number of person days of employment generated, funds released and utilised, nature and number of works ongoing and completed etc., is collected from the zilla panchayat, Taluk panchayat, and Gram panchayat offices and also from NREGA website. Based on the amount of expenditure made under MGNREGS and number of person days of employment generated, which were found higher in the ten villages namely Avalagurki, Gerahalli, Thippenahalli, Kurlahalli, Avalagurki, Kournahalli, Gollahalli, Ittappanahall, and Kethenahalli these villages from Chikkaballapura district were selected through Multi-stage sampling. The total sample size taken was 300 , out of which 200 were MGNREGS participants in MGNREGS and 100 were non participants having the same socioeconomic background from the ten selected villages, were randomly selected for eliciting information from the respondents.

\section{Results}

The results that emerged from the analysis of the data are presented under the following broad headings.

1) Socio-economic features of the respondent households.

2)To estimate the complementary benefits of MGNREGS on income, expenditure and savings pattern of MGNREGS participants

3) To assess the economic empowerment of women through MGNREGS.

\section{Composition of sample respondent households}

Number of participants in MGNREGS works in sample area was (200) and non participants (100) participants the total sample 300 participants similarly all 10 villages equally selected. respectively.
Table 1: Number of registered workers in MGNREGS in the sample Villages

\begin{tabular}{|c|c|c|}
\hline Classes & Participants $(N=200)$ & Non -participants $(N=100)$ \\
\hline SCs & 89 & 45 \\
& $(45)$ & $(45)$ \\
\hline STs & 42 & 21 \\
& $(21)$ & $(21)$ \\
\hline BPL & 69 & 35 \\
& $(35)$ & $(35)$ \\
\hline Total & $\mathbf{2 0 0}$ & $\mathbf{1 0 0}$ \\
& $(\mathbf{1 0 0 . 0 0 )}$ & $\mathbf{( 1 0 0 . 0 0 )}$ \\
\hline
\end{tabular}

Note: Figures in parentheses indicate percentage to the total

The Table 2 reveals that, the average annual wage income earned by the women participants from MGNREGS works was Rs 5167 while from agricultural work it was Rs 7609 and by the men participants was Rs 6050 and Rs 14506 from MGNREGS works and agriculture respectively. Although, there was a slight difference in the average annual wage income earned from MGNREGS by women and men participants, the difference was not statistically significant

The average annual wage income earned by the SC/ST participants from MGNREGS works was Rs 6242 and from agricultural labour works was Rs 14706 and by other category participants was Rs 4941 and Rs 13692 respectively. Although the average annual wage income earned from MGNREGS is more for SC/ST participants than others, the difference was not statistically significant

The average annual wage income earned by BPL participant households from MGNREGS and agricultural labour work was Rs 5695 and Rs 13542 respectively and that of APL participant families was Rs 5400 and Rs 12120 respectively.

Table 2: Average annual wage income earned by different classes of sample respondents (Rupees)

\begin{tabular}{|c|c|c|c|c|}
\hline \multirow{2}{*}{$\begin{array}{c}\text { (Rupees) } \\
\text { Average annual wage } \\
\text { income of respondents }\end{array}$} & \multicolumn{3}{|c|}{ Participants $(\mathrm{N}=200)$} & \multirow{2}{*}{$\begin{array}{l}\text { Non participants } \\
(\mathrm{N}=100)\end{array}$} \\
\hline & $\begin{array}{l}\text { MGNREGS } \\
\text { work }\end{array}$ & $\begin{array}{l}\text { Agriculture } \\
\text { Labour work }\end{array}$ & Total wage income & \\
\hline Men & $\begin{array}{c}6050 \\
(29.43) \\
\end{array}$ & $\begin{array}{c}14506 \\
(70.57) \\
\end{array}$ & 20556 & 24694 \\
\hline women & $\begin{array}{c}5167 \\
(40.44) \\
\end{array}$ & $\begin{array}{c}7609 \\
(59.56) \\
\end{array}$ & 12776 & 8100 \\
\hline $\mathrm{SC} / \mathrm{ST}$ & $\begin{array}{c}6242 \\
(29.80)\end{array}$ & $\begin{array}{c}14706 \\
(70.20)\end{array}$ & 20948 & 19771 \\
\hline Others & $\begin{array}{c}4941 \\
(26.52)\end{array}$ & $\begin{array}{l}13692 \\
(73.48)\end{array}$ & 18633 & 26286 \\
\hline BPL & $\begin{array}{c}5695 \\
(29.60)\end{array}$ & $\begin{array}{c}13542 \\
(70.40)\end{array}$ & 19237 & 19082 \\
\hline
\end{tabular}

Source : Survey data (2013-14)

Wage employment details of sample respondents.

As given in the Table 3, the average person days of employment per year was found to be increased from 165.4 days to 222.5 days after the implementation of MGNREGS, reflecting 34.52 per cent increase over the base level. Similarly the average number of labour force per family, which was 2.0, also increased to 2.3 members after the implementation of MGNREGS in case of participant households.
Table 3: Wage employment details of sample respondents

\begin{tabular}{|c|c|c|}
\hline Particulars & $\begin{array}{c}\text { Before } \\
\text { MGNREGS }\end{array}$ & $\begin{array}{c}\text { After } \\
\text { MGNREGS }\end{array}$ \\
\hline $\begin{array}{l}\text { Average person days of } \\
\text { employment per year }\end{array}$ & 165.4 & $\begin{array}{c}222.5 \\
(34.52) \\
\end{array}$ \\
\hline $\begin{array}{l}\text { Average number of labour force } \\
\text { per family }\end{array}$ & 2.0 & $\begin{array}{c}2.3 \\
(15.00)\end{array}$ \\
\hline $\begin{array}{c}\text { Average annual wage income } \\
\text { earned (Rs) }\end{array}$ & 16726.7 & $\begin{array}{c}18301.65 \\
(27.34)\end{array}$ \\
\hline
\end{tabular}




\section{International Journal of Science and Research (IJSR) \\ ISSN (Online): 2319-7064}

Index Copernicus Value (2015): 78.96 | Impact Factor (2015): 6.391

Note: Figures in parantheses indicate percentage increase in person days, number of persons working and annual wage income earned by the participants after the implementation of MGNREGS.

\section{Labour participation in agricultural work}

As given in the Table 4, the average number of person days participated by the respondents in agricultural work decreased from 80.39 days before MGNREGS to 66.27 days after MGNREGS in Kharif season with a percentage decline of 17.55. Whereas in Rabi and Summer seasons, it was 64.12 days before MGNREGS and 30.39 days after MGNREGS and percentage decline was 52.60 per cent. The total average number of person days worked as agricultural labour declined from 122.83 days to 82.17 days in a year $(33.11 \%)$.

Table 4: Labour participation in agricultural work

\begin{tabular}{|c|c|c|c|}
\hline Season & $\begin{array}{c}\text { Before } \\
\text { MGNREGS }\end{array}$ & $\begin{array}{c}\text { After } \\
\text { MGNREGS }\end{array}$ & $\begin{array}{c}\text { Decreased } \\
\text { participation }\end{array}$ \\
\hline Kharif & 80.39 & 66.27 & $\begin{array}{c}14.12 \\
(17.55)\end{array}$ \\
\hline Rabi and Summer & 64.12 & 30.39 & $\begin{array}{c}33.73 \\
(52.60)\end{array}$ \\
\hline Total & 122.83 & 82.17 & $\begin{array}{c}40.67 \\
(33.11)\end{array}$ \\
\hline
\end{tabular}

Note: Figures in parentheses indicate the percentage decline

\section{Summary and Conclusion}

Government of India has taken up several poverty and unemployment alleviation programmes to solve this problem to the extent possible and to increase the standard of living of the rural poor. The most significant intervention made by the Government of India to generate employment is in the form of MGNREGA - Mahatma Gandhi National Rural Employment Guarantee Act 2005-06. It is the world's largest employment guarantee programme implemented in India. It aims at enhancing livelihood security of households in rural areas of the country by providing at least 100 days of guaranteed wage employment in a financial year to every household whose adult members volunteer to do unskilled manual work. Its primary objective is augmenting wage employment and strengthening natural resource management. Job cards are issued for all the workers seeking employment for the maintenance of identity. Unemployment allowance is paid, if work is not assigned within 15 days of submitting application form seeking employment. Wages are paid to the workers through their savings account opened in banks or post offices. Use of machinery which replaces human labour is minimized. Providing work site facilities like shade, clean drinking water, First-aid box, crèche for children below five years of age have been made mandatory

\section{Policy Implications}

1) Monitoring and social auditing of MGNREGS works must be made still more effective so as to ensure payment of wages in time, only through bank or post office accounts, and issuing of job cards to all the registered households under MGNREGS without any delay and hassles.
2) MGNREGS is the most prominent programme initiated by Government of India to provide employment to rural people and thereby improve their livelihood security. The present study has pointed out that the programme has affected the supply of labour to agriculture in a few cases after its implementation. Hence, the programme needs to be reoriented, so that it becomes complementary to progress in agricultural sector by executing MGNREGS works only during the off season.

\section{References}

[1] AIYAR YAMINI AND SAMJI, SALIMAH, 2006, improving the effectiveness of National Rural Employment Guarantee Act. Economic and Political Weekly, 41(04): 320-326.

[2] CHAKRABORTY, PINAKI, 2007, Implementation of employment guarantee: a preliminary appraisal. Economic and Political Weekly, 42(07): 548-551.

[3] KHERA, R. AND NAYAK, N., 2009, Women workers and perceptions of the National Rural Employment Guarantee Act. Economic and Political Weekly, 44(43): 49-57.

[4] SINGH, J. N. AND MISHRA, A., 2006, Backward linkages of rural employment guarantee scheme. Kurukshetra, 54(10): 30-34. 